\title{
Assessment of Capacitance for Self-Excited Induction Generator in Sustaining Constant Air-Gap Voltage under Variable Speed and Load
}

\author{
Ashish Sharma and Gagandeep Kaur * (D) \\ Electrical Engineering, I. K. Gujral Punjab Technical University Jalandhar, Kapurthala, Punjab 144603, India; \\ ashishdpr@rediffmail.com \\ * Correspondence: gaganee@ptu.ac.in; Tel.: +91-947-809-8118
}

Received: 1 September 2018; Accepted: 17 September 2018; Published: 20 September 2018

\begin{abstract}
The concept of a Self-Excited Induction Generator (SEIG) has introduced the concept of the placement of an induction machine for power generation in an isolated mode with external capacitance. The produced output voltage and generated frequency in an SEIG greatly depends on speed, load, and terminal capacitance. To maintain constant air-gap voltage against a varying speed and load, a corresponding supply of reactive power through capacitors is needed. The selection of the required capacitance while there is continuous variation of vital parameters needs a rigorous random-selection method. In this paper, an intelligent selection of suitable additional capacitance has been made by using the Fuzzy Logic Technique for a Three-Phase 5.0 HP SEIG. Additional capacitance in the range of $14.79-22.47 \mu \mathrm{F}$ is compulsory under a varying load of $427-101 \mathrm{ohms}$, and additional capacitance in the range of $13.70-22.59 \mu \mathrm{F}$ is essential for a varying speed of 1349 to $1672 \mathrm{RPM}$. With this promising result, we propose the implementation of this intelligent technique in place of analytical and standard methods for capacitance selection.
\end{abstract}

Keywords: self-excited induction generator; load; speed; capacitance

\section{Introduction}

The indiscriminate utilization of fossil fuels to meet the ever-growing energy demand of the worldwide population has in all increased the total global figure for the production of greenhouse gases (GHG) by three quarters [1]. These GHG emissions are a major contributor to global warming and stand as the biggest hurdle for upcoming generations. The changing scene of ultramodern living and a manyfold population rise has raised energy demands. To fulfill these rising energy demands, alternative sources of energy need to be identified and exploited on a large scale. It has also necessitated the need for a sustainable and green energy source. Renewable-energy sources, such as solar, wind, biomass, and hydro are sustainable, environmentally safe, and green sources of energy. Additionally, the recent development of deregulation and decentralization of the power-generation system has given birth to the concept of distributed generation by using renewable-energy resources [2]. Commissioning distributed generation through the exploitation of renewable energy resources near load centers requires a conversion-efficiency device like a generator. Usage of an induction machine as generator is well-received as a renewable energy resource [3-7]. Induction machines, coupled to an external prime mover and running at a speed above the synchronous speed with grid frequency, are capable of generating power at a negative slip. In the negative-slip region, the induced torque direction is reversed, the machine starts behaving as an induction generator, and it draws a current that lags behind the voltage with an angle greater than $90^{\circ}$ [8]. This indicates the outflow of real power from the machine, but to maintain real and reactive power balance, the machine needs the reactive power. 
For the induction generator, sufficient voltage buildup across generator terminals requires a means for excitation, and, consequently, the generator can work in grid-connected mode or -isolated mode. For grid-connected induction generators, the extraction of reactive power can be done through the grid, but this burdens the grid. The remedial measure for the same could be by connecting the capacitor bank across generator terminals. For the isolated mode of an induction generator, an appropriate capacitor bank must be connected across generator terminals, and the phenomenon of connecting capacitors is known as capacitor self-excitation. This induction generator is called a Self-Excited Induction Generator (SEIG) [9-11].

\subsection{Self-Excited Induction Generator}

The conception of self excitation of induction machines emerged in 1935 with the notion that an induction machine in isolated mode can act as an induction generator with an external capacitor. The function of capacitance connected at stator terminals is to provide the required reactive power to fulfill the needs of the generator and load. SEIGs have the advantages of a small size, single excitation, and self-protection capability, and have wide applications in wind-power generation. In SEIGs, there is no issue of synchronization of the generated voltage with the bus-bar voltage of the system. The dependence of vital parameters, such as output voltage and frequency of SEIG on speed, load, and terminal capacitance imposes a restriction on its usage. An SEIG with a fixed value of capacitance rises to a difference between reactive powers supplied by shunt capacitors and required by the load, which further leads to poor voltage regulation $[12,13]$. So, at all possible speeds and loadings, a fixed capacitor cannot provide sufficient amount of reactive power. Even the average capacitances provided by fixed capacitors might not be helpful due to excessive overvoltages. Inadequate capacitance does not allow the generator to build up voltage, and over-rated capacitance suddenly raises the voltage on load removal and transient temperature. Hence, the selection of additional or suitable capacitance under varying generator speed and loads needs artificial intelligence or optimization techniques to counter the two listed major drawbacks of induction generators. For the selection of suitable capacitance information of performance characteristics, operating conditions, parameters, and terminal conditions are prerequisites.

\subsection{Literature Review}

Hammad et al., (1977) introduced the concept of designing thyristor phase-controlled voltage regulators for cost-effective voltage regulation at frequency-sensitive varying loads for optimized output voltage [13]. Ooi et al., (1979) proposed the synchronous condenser to compensate for machines' reactive power requirements for wind-turbine power [14]. Singh et al., (1990) developed an algorithm for the number of capacitors required to generate voltage for the rated capacity loading of a machine [15]. Murthy et al., (1993) examined the capacitance requirements of an SEIG with the addition of a single parallel capacitor for each phase [16]. Bhim et al., (1995) performed approximate analysis for a long-shunt SEIG for series estimation and for shunt capacitors to meet reactive-power requirements [17]. Ojo et al., (1996) stated that with the addition of short-shunt and long-shunt excitation connections, the performance of single-phase induction generators could be improved [18]. Wang et al., (1999) suggested that, if an SEIG is supplying a constant load at a fixed speed, then a single capacitor is ideal for reactive power requirements [19]. Chan et al., (2002) presented a practical method for the computation of minimum capacitance to initiate voltage buildup for SEIG using the iterative secant method [20]. Seyoum et al., (2003) said that intricate excitation and control strategies are required due to fluctuating output voltage and frequency [21]. Ahmed et al., (2003) introduced the nodal admittance approach steady-state frequency-domain analysis for determining minimum excitation capacitance. A static VAR compensator (SVC) has been in parallel to a thyristor-phase control reactor (TCR) and thyristor switched capacitor (TSC) for reactive power compensations [22]. Singh et al., (2009) took the multivariable unconstrained nonlinear optimization problem for minimum excitation capacitance [23]. Khela et al., (2011) applied the Artificial Neural Network (ANN) model for 
estimation of capacitance requirements with a variable load [24]. Haque et al., (2012) presented the determination of excitation capacitance for building no-load voltage for off-grid SEIG operations [25]. Kumar et al., (2013) introduced a new, simple, and direct method of analyzing the complex impedance matrix of generators while being connected with an R-L load to predict the minimum capacitance value [26]. A. Abbou et al., (2013) applied the loop and nodal analysis method, named direct method, to obtain the criteria for maintaining performance characteristics of a three-phase SEIG in isolated mode [27]. Faisal et al., (2014) presented a steady-state model and analysis for single-phase SEIGs for optimum capacitance against inductive and resistive loads [28]. Alok et al., (2016) presented a mathematical model using node admittance for six-phase induction generators for excitation capacitance by using a genetic algorithm [29]. Mhamdi Taoufik et al., (2017) developed a wind generator for rural electrification, and many experimental tests were performed to define parameters and convenient capacitor bank [30]. Khaled S Sakkoury et al., (2017) performed analysis, modeling, and simulation of wind-driven SEIGs under dynamic conditions [31].

\subsection{Paper Overview}

The present paper is divided into four broad sections. Section 1 introduces SEIGs and the literature review relevant to the paper subject. Section 2 describes the need and reasons for standard tests, and applies an analytical technique for analysis of SEIG. It introduces a new fuzzy-logic technique for analysis and determination of capacitance requirements for maintaining of a constant air-gap voltage. Section 3 reports the available data required for further computation and presenting the result outcomes with the implementation of the above-quoted techniques. Section 4 evidently concludes capacitance requirements for the maintenance of a constant air gap.

This paper proposes the artificial-intelligence fuzzy-logic technique for determination of intelligently selected capacitance to maintain a constant air gap under varying speed and load. Optimized capacitance values were verified with the analytical and standard test method, and they were experimented on a four-pole three-phase self-excited induction generator of a $5.0 \mathrm{HP}$ power rating. The chief purpose of the application of the fuzzy-logic technique on SIEGs is to generalize the algorithm for all ratings and types of SEIGs without long calculations of analytical methods and randomized experimental selection of appropriate capacitance. The benefit of the fuzzy-logic technique is that it is a simple rule-based technique on membership-function formation. The main point behind the experimental verification of selected capacitance was for testing and validating fuzzy-logic results.

\section{Materials and Methods}

The schematic of an SEIG shows that it has four parts: the prime mover, machine, load, and capacitance for the purpose of self-excitation, as shown in Figure 1. To keep the machine acting as an induction generator, reactive power is fed, as per the simple principle.

Real power generated $\left(\mathrm{P}_{\mathrm{g}}\right)=$ real power consumed by load $\left(\mathrm{P}_{\mathrm{L}}\right)$.

Reactive power for load = reactive power supplied by capacitor-Reactive power for generator

$$
\mathrm{Q}_{\mathrm{L}}=\mathrm{Qc}-\mathrm{Qg}
$$

Steady-state analysis of any machine is always curious from a design and operation point of view. Similarly for an SEIG, when it operates in isolated mode, terminal voltage and frequency are unidentified and based on known or measured parameters that need to be computed at a given speed, load impedance, and capacitance. A large number of researchers have presented their work on SEIG steady-state analysis [32-37]. Various models, such as the D-q Reference Model, Impedance-Based, Admittance-Based, Operational Circuit-Based, and Power Equations-Based models have been presented by researchers for SEIG analysis [34,38-41]. The above methods engage advanced polynomial equations for generated frequency and magnetizing reactance, the coefficients of which can be solved using an SEIG impedance network. The commonly used methods for steady-state 
analysis of any induction machine are the standard-test method and analytical method. By performing the standard test on a machine, unknown parameters can be measured or calculated. In the second method, the parameters of an equivalent machine circuit are determined by solving the equivalent machine circuit. Both of these methods have been applied on the machine under study.

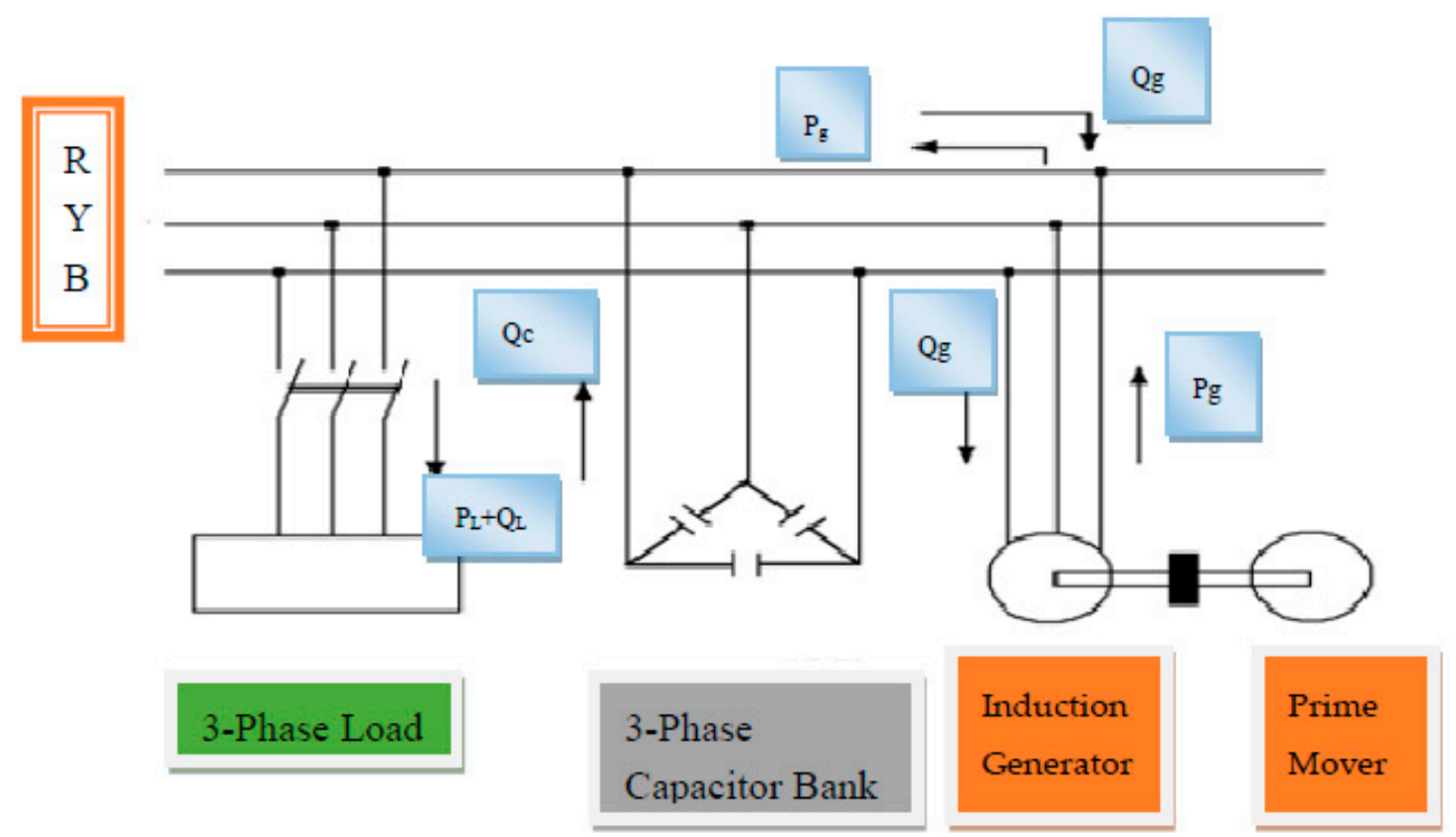

Figure 1. Schematic of a Self-Excited Induction Generator (SEIG).

\subsection{Standard Tests for Analysis of Self-Excited Induction Generator}

For the SEIG analysis, the data about its performance characteristics at any load must be known, which is possible through a standard No-Load or Block-Rotor Test, or can be taken from design data. The purpose of this standard test is to predetermine the performance characteristics of a machine at any load without actually loading it. An experimental approach has been adopted in this study for determination of stator resistance, rotor resistance, stator leakage reactance, rotor leakage referred to stator, magnetizing reactance (unsaturated), magnetizing reactance (saturated), and equivalent resistance in place of the generator's core-loss branch [42,43]. The new addition of magnetizing reactance (saturated) is due to the self-excitation of an induction generator. Voltage build-up in a generator is only possible when it enters into the saturated region. The state of entering this region relies on its speed, excitation capacitance, and load. For a particular machine, there exists a definite relationship between air-gap-induced voltage and saturated magnetizing reactance, which further depends on the magnetizing characteristics of the magnetic material used for stator and rotor. To establish the relationship between these two vital parameters, a Synchronous Run Test was performed on the machine by running the induction motor at synchronous speed corresponding to the supply frequency.

The detailed procedure to perform a synchronous run test on the machine under study was as follows. The schematic of this setup is shown in Figure 2, depicting that the three-phase induction motor, coupled with the prime mover, was attached to a power-quality analyzer to measure input voltage, current, power, and power factor. Here, the machine ran as a motor at no load by supplying power at a rated voltage and frequency. Then, the prime mover was supplied to provide torque to the induction motor in same direction. The speed of the prime mover was adjusted to achieve synchronous speed of setup at rated frequency. The input voltage was then varied from low to rated voltage against synchronous speed at a rated frequency, and measurements were made at each step to demonstrate magnetizing characteristics. At that stage, the induction machine drew only the magnetizing current 
from the supply that maintains air-gap voltage. In this case, active power drawn by the stator was zero, owing to the zero power factor of the stator current. From these experimental data, air-gap voltage and the corresponding value of magnetizing reactance was determined as mentioned below:

$$
\begin{gathered}
\text { Magnetizing Current } I_{m}=\text { Phase Current } I_{p h} \\
\text { Per Phase Stator Impedance } Z_{p h}=V_{p h} / I_{p h} \\
\text { Air-gap Voltage per phase at rated frequency } E_{1}=V_{p h}-\left(R_{s}+j X_{l s}\right)\left(-j I_{m}\right) \\
\text { Saturated Reactance } X_{m}=E_{1} / I_{m} \\
\text { Saturated Reactance } X_{m}=\left(Z_{p h}{ }^{2}-R_{s}\right)^{1 / 2}-X_{l s}
\end{gathered}
$$

$V_{\mathrm{ph}}=$ per phase applied voltage, $X_{1 \mathrm{~s}}=$ stator leakage reactance, $R_{\mathrm{s}}=$ Stator resistance.

The relationship of $X_{m}$ and $E_{1}$ was established by using a piecewise linearization technique. This model was further used for SEIG performance analysis under different loading conditions.

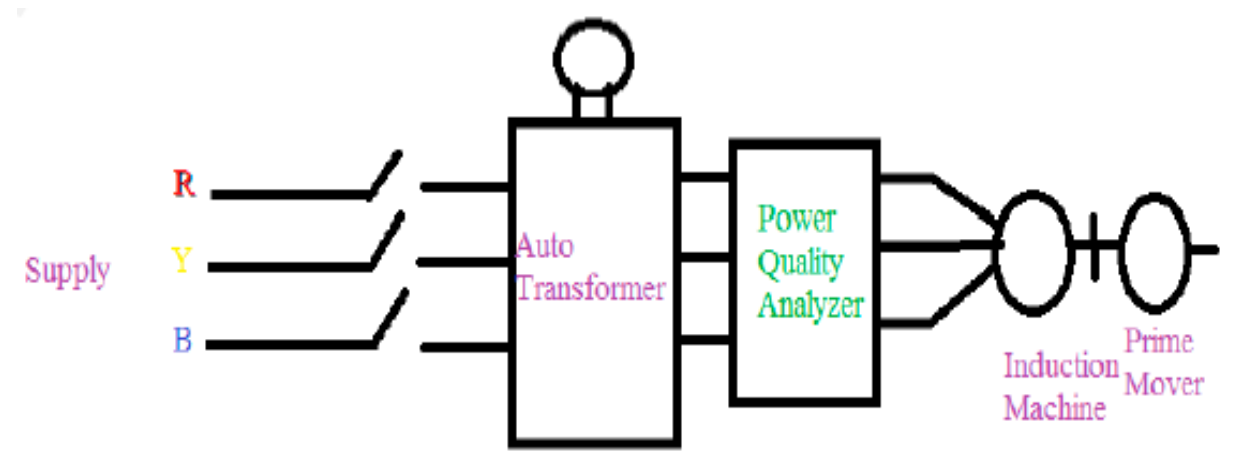

Figure 2. Setup of Synchronous Run Test.

\subsection{Analytical Technique for Analysis of Self-Excited Induction Generator}

For implementation of the analytical technique, the per-phase SEIG-equivalent circuit with rotor parameters referred to the stator side is shown in Figure 3. A core-loss branch was included in the equivalent circuit, though its effect was insignificant on machine performance. This equivalent circuit was with reference to the rated machine frequency and making the resistance parameters of circuit as frequency-sensitive [11,44]. From the circuit, the impedances of different branches seen from respective nodes are:

$$
\begin{gathered}
Z_{A H}=R_{L} / a+j X_{L}, Z_{B G}=-j X_{c} / a^{2} \\
Z_{B C}=R_{s} / a+j X_{s} ; Z_{C F}=R_{e} / a|| j X_{m} \\
Z_{C E}=R_{r} /(a-b)+j X_{r} \\
Z_{\text {Total }}=\left[\left(R_{e} / a|| j X_{m}\right)||\left(R_{r} /(a-b)+j X_{r}\right)\right]+R_{s} / a+j X_{s}+\left[\left(R_{L} / a+j X_{L}\right)+\left(-j X_{c} / a^{2}\right)\right]
\end{gathered}
$$

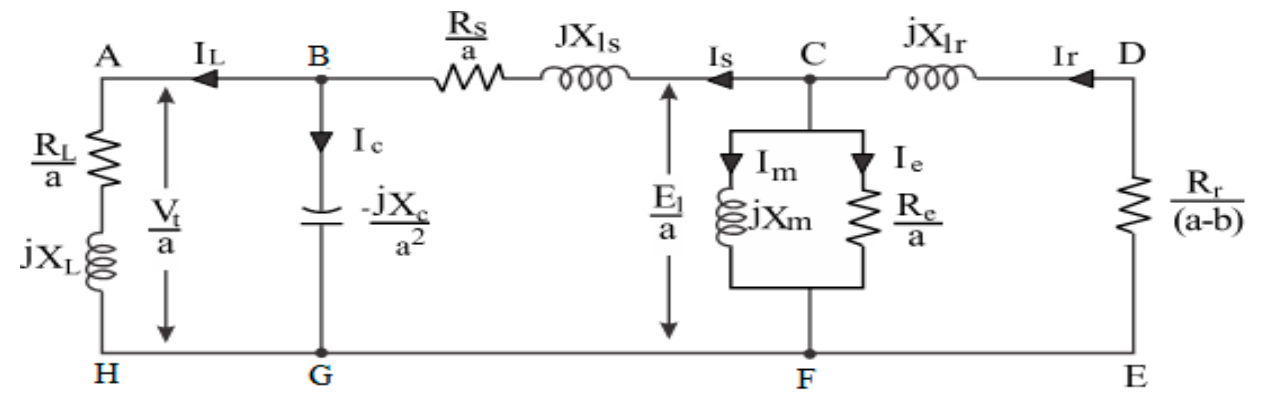

Figure 3. Equivalent circuit of SEIG (per phase). 
The equivalent circuit results in a single-loop equation:

$$
\text { Is } \times \mathrm{Z}_{\text {Total }}=0
$$

For successful voltage build-up, Is $\neq 0$, Thus

$$
\mathrm{Z}_{\text {Total }}=0
$$

The details of equivalent circuit parameters are in Nomenclature. By separating the real and imaginary components of the equation, two nonlinear simultaneous equations were obtained in terms of machine parameters, speed, capacitive reactance, load resistance, magnetizing reactance, and generated frequency. By putting the real and imaginary part of the equation separately equal to zero, the obtained equations are:

$$
\begin{aligned}
& \text { Real }\left(X_{m}, a\right)=P_{1} X_{m} a^{5}+P_{2} X_{m} a^{4}+\left(P_{3} X_{m}+P_{4}\right) a^{3}+\left(P_{5} X_{m}+P_{6}\right) a^{2}+\left(P_{7} X_{m}+P_{8}\right) a+P_{9} X_{m}+P_{10} \\
& \text { Imaginary }\left(X_{m}, a\right)=\left(Q_{1} X_{m}+Q_{2}\right) a^{4}+\left(Q_{3} X_{m}+Q_{4}\right) a^{3}+\left(Q_{5} X_{m}+Q_{6}\right) a^{2}+\left(Q_{7} X_{m}+Q_{8}\right) a+Q_{9}
\end{aligned}
$$

The coefficients $\mathrm{P}_{1}-\mathrm{P}_{10}$ and $\mathrm{Q}_{1}-\mathrm{Q}_{9}$ of the two equations were obtained using MATLAB and are given in Nomenclature. These are solved using the Newton Raphson Method in MATLAB, and the value of ' $X_{m}$ ' and ' $a$ ' was calculated. The value of ' $E_{1}$ ' was determined from magnetizing characteristics. To determine ' $X_{m}$ ' and ' $a$ ' with this technique, we engaged tedious mathematical computations and lengthy computer programming.

The branch currents, terminal voltages, and output power of SEIG were determined as follows:

$$
\begin{gathered}
\text { Stator Current } I_{s}=\left(E_{1} / a\right) / Z_{B C}+\left(Z_{B G}+Z_{A H}\right) \\
\text { Rotor Current } I_{r}=\left(-E_{1} / a\right) / Z_{C E} \\
\text { Magnetizing Current } I_{m}=\left(E_{1} / a\right) / j X_{m} \\
\text { Core-Loss Branch Current } I_{e}=\left(E_{1} / a\right) /\left(R_{e} / a\right) \\
\text { Load Current } I_{L}=I^{*}\left(-j X_{c} / a^{2}\right) /\left[R_{L} / a+j\left(X_{L}-X_{c} / a^{2}\right)\right] \\
\text { Terminal Voltage } V_{t} / a=\left(E_{1} / a\right)-I_{s}\left(R_{s} / a+j X_{l s}\right) \\
\text { Generated Power Po }=3 I_{L}{ }^{2} R_{L} / a
\end{gathered}
$$

2.3. Fuzzy Technique for Analysis and Determination of Capacitance to Maintain Constant Air-Gap Voltage of Self-Excited Induction Generator

To solve the polynomial equations of analytical techniques, rigorous calculations were involved, which is quite a time-consuming task and may lead to calculation errors. Fuzzy technique is a tool that resolves all these issues and makes the determination of parameters simple, fast, and accurate. It is used here to find the per-unit value of generated frequency ' $a$ ' and saturated magnetizing reactance ' $X_{\mathrm{m}}$ '. A rule-based method was used, limits on each parameter were fixed, and fuzzy sets were classified into various linguistic variables; from that, membership functions were formed.

- The 9 given inputs were stator-leakage reactance $X_{s}$, rotor-leakage reactance $X_{r}$, stator resistance $R_{S}$, rotor resistance $R_{r}$, core-loss resistance $R_{c}$, speed $N$, power factor $P F$, capacitance $C$, and load admittance $\mathrm{Y}$.

- The 2 outputs were generated frequency ' $a$ ' and magnetizing reactance $X_{m}$. All input and output parameters are in per-unit values.

- The range and naming of input membership functions and output membership functions were extreme low (EL), very low (VL), low (L), medium $(\mathrm{M})$, high $(\mathrm{H})$, and very high $(\mathrm{VH})$. By adjusting 
the range of the membership functions, more rules are formed and high rate of result accuracy can be achieved.

The input-output parameters calculated from the analytical technique or by using any standard method are proposed as the fuzzy rule. To find the input parameters, MATLAB programming was used, and the parameter range was selected as per the real-time SEIG applications.

The fuzzy model was implemented to find the generated frequency and magnetic reactance requirements of SEIG under varying stator and rotor resistance, and stator and rotor reactance.

The excitation process of SEIG is greatly influenced by variation in terminal parameters like speed and load, which leads to a reduction in terminal voltage. When an induction generator runs in isolated mode, its terminal voltage decreases due to a decrease in air-gap voltage. To maintain this air-gap voltage, minimum excitation capacitance for excitation and additional capacitance are required. To regulate this capacitance requirement, the fuzzy model was proposed for implementation that would compute the capacitance requirement to maintain constant air-gap voltage. In the previous fuzzy model for parameter determination, 9 inputs and 2 outputs were taken. In the present model, an additional input of change in capacitance $\Delta C$ was taken. For constant air-gap magnetizing, reactance should be constant.

For maintaining constant air-gap voltage for varying speed under constant load and excitation capacitance, the membership function for all parameters except speed and change in capacitance were kept as constant. Speed membership functions are extreme low (EL), very low (VL), medium (M), high $(\mathrm{H})$, and very high $(\mathrm{VH})$, and membership functions for change in capacitance are negatively large (NL), negatively medium (NM), negatively small (NS), positively small (PS), and positively large (PL). For implementation of the fuzzy rule for a constant air gap, 25 rules were made. The first rule, when speed is extremely low (EL) and $\Delta \mathrm{C}$ is negatively small, magnetizing reactance is high and generated frequency is low. The other rules are similarly defined and used in the implementation of the model.

It is observed that no-load voltage of SEIG generally varies (110-125\%) and the generator fails to excite when its saturated magnetizing reactance attains a value close to unsaturated magnetizing reactance. So, limits have been suggested to impose based on the standard limits of other machines. For unsaturated magnetizing reactance $X_{m}$, minimum magnetizing reactance $X_{\min }$, maximum no-load air-gap voltage $E_{\max }$ and minimum air-gap voltage at rated load $E_{\min }$, the limits are 2.0-5.0 p.u., $0.45-0.65$ p.u., $1.10-1.50$ p.u., and $0.45-0.65$ p.u., respectively.

\section{Data Reporting and Results}

SEIG has the capability to work in two modes, i.e., grid-connected and isolated mode. In both modes, the smooth operation of the induction generator is the utmost priority for the generation of terminal voltage and power. For the successful operation of an SEIG in isolated mode, it is important to meet the reactive power requirements, which is possible by integrating the minimum value of capacitance. Before the intelligent selection of appropriate capacitance, the prerequisite is to determine the unknown parameters of the SEIG-equivalent circuit. The step-by-step results of this study are presented below:

\subsection{Specifications of Induction Machine}

For the present research work, a Squirrel-Cage Three-Phase Induction Machine was selected, and Table 1 presents the information about its machine specifications: 
Table 1. Specifications of induction machine.

\begin{tabular}{ccccccc}
\hline $\begin{array}{c}\text { Type of } \\
\text { Machine }\end{array}$ & $\begin{array}{c}\text { Power } \\
\text { Rating (HP) }\end{array}$ & $\begin{array}{c}\text { Voltage } \\
\text { Rating (volt) }\end{array}$ & $\begin{array}{c}\text { Current } \\
\text { Rating (Amp) }\end{array}$ & $\begin{array}{c}\text { Speed } \\
\text { (RPM) }\end{array}$ & $\begin{array}{c}\text { No. of } \\
\text { Poles }\end{array}$ & $\begin{array}{c}\text { Type of } \\
\text { Connection }\end{array}$ \\
\hline $\begin{array}{c}\text { Three-Phase } \\
\text { Induction } \\
\text { Machine }\end{array}$ & 5.0 & 415 & 7.60 & 1500 & 4 & Delta \\
\hline
\end{tabular}

\subsection{Determination of Machine Parameters and Magnetizing Characteristics with Standard Test}

For the determination of the machine's technical parameters, the No-load and Block-Rotor Test were performed on the machine under study, and results are tabulated in Tables 2 and 3.

Table 2. Base parameters of induction machine.

\begin{tabular}{cccccccc}
\hline $\begin{array}{c}\text { Voltage } \\
(\text { Volt })\end{array}$ & $\begin{array}{c}\text { Current } \\
(\mathbf{A m p})\end{array}$ & $\begin{array}{c}\text { Power } \\
(\mathbf{V A})\end{array}$ & $\begin{array}{c}\text { Frequency } \\
(\mathbf{H z})\end{array}$ & $\begin{array}{c}\text { Speed } \\
(\mathbf{R P M})\end{array}$ & $\begin{array}{c}\text { Impedance } \\
(\mathbf{O h m})\end{array}$ & $\begin{array}{c}\text { Admittance } \\
(\mathbf{M h o})\end{array}$ & $\begin{array}{c}\text { Capacitance } \\
(\boldsymbol{\mu \mathbf { F }})\end{array}$ \\
\hline 415 & 4.33 & 1797 & 50 & 1500 & 95.84 & 0.010 & 25.46 \\
\hline
\end{tabular}

Table 3. Parameters of induction machine.

\begin{tabular}{cccccc}
\hline $\begin{array}{c}\text { Stator } \\
\text { Resistance } \\
\text { (p.u) }\end{array}$ & $\begin{array}{c}\text { Rotor } \\
\text { Resistance } \\
\text { (p.u) }\end{array}$ & $\begin{array}{c}\text { Stator-Leakage } \\
\text { Reactance } \\
\text { (p.u) }\end{array}$ & $\begin{array}{c}\text { Rotor Leakage } \\
\text { Reactance } \\
\text { (p.u) }\end{array}$ & $\begin{array}{c}\text { Core-Branch } \\
\text { Resistance } \\
\text { (p.u) }\end{array}$ & $\begin{array}{c}\text { Magnetizing } \\
\text { Reactance } \\
\text { Unsaturated (p.u) }\end{array}$ \\
\hline 0.061 & 0.0437 & 0.097 & 0.097 & 32.53 & 2.973 \\
\hline
\end{tabular}

The experimental-data relationship of magnetizing reactance ' $X{ }_{m}$ ' and corresponding air-gap voltage ' $E_{1}$ ' of induction machine is established with a synchronous run test, and determination of these two parameters was done as follows. Characteristics are shown in Figure 4.

$$
\begin{gathered}
X_{m}<2.693 \text { p.u, } E_{1}=1.3818-0.2117 X_{m} \text { p.u } \\
X_{m}<2.838 \text { and } X_{m} \geq 2.693, E_{1}=2.1679-0.5057 X_{m} \text { p.u } \\
X_{m}<2.971 \text { and } \geq 2.838, E_{1}=3.8732-1.1057 X_{m} \text { p.u } \\
X_{m}>2.9716, E_{1}=0
\end{gathered}
$$

Magnetizing Characteristics

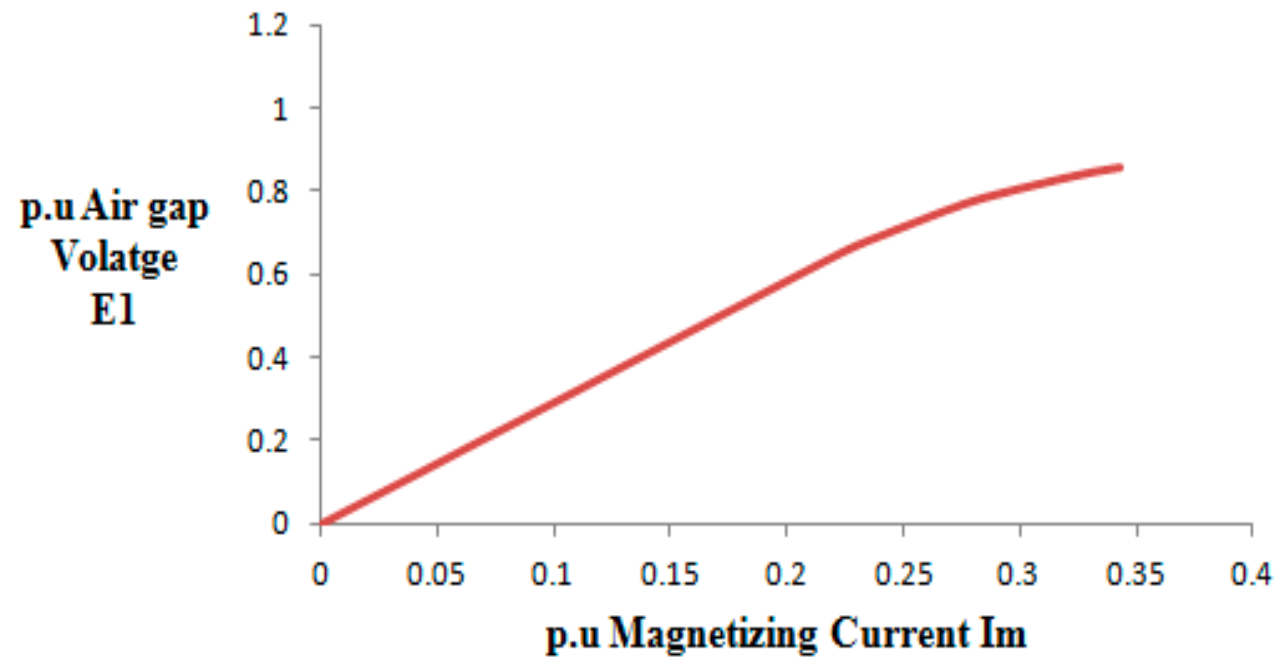

Figure 4. Magnetizing Characteristics of Machine. 
All mesurements are done on standard measuring devices of OSAW Company and Power Quality Analyzer Model No. C.A.8332, CHAUVIN ARNOUX MAKE.

For the performance analysis of any system or machine, per unit values are the preferred method of data demonstration, so base values of machine has been determined to define p.u values. As magnetizing current of machine increases in steps the voltage build-up starts in machine and simultaneously air gap voltage increases and finally reaches close to 1.0 p.u.

\subsection{Determination of Machine Parameters with Analytical Technique}

The conventional equivalent circuit of machine for SEIG is solved by using the Equations (6)-(17) and results with analytical technique for magnetizing reactance, generated frequency, terminal voltage and output power with varying load, speed and excitation capacitance are described in Tables 4-7.

Table 4. Magnetizing Reactance and Generated Frequency of SEIG with varying Load for Analytical and Fuzzy Techniques, Speed $=1485$ RPM, Excitation Capacitance $=27.57 \mu \mathrm{F}$.

\begin{tabular}{ccccc}
\hline $\begin{array}{c}\text { Load } \\
\text { Admittance } \\
\text { (p.u) }\end{array}$ & $\begin{array}{c}\text { Magnetizing } \\
\text { Reactance (p.u) } \\
\text { Analytical }\end{array}$ & $\begin{array}{c}\text { Magnetizing } \\
\text { Reactance (p.u) } \\
\text { Fuzzy }\end{array}$ & $\begin{array}{c}\text { Generated } \\
\text { Frequency 9 (p.u) } \\
\text { Analytical }\end{array}$ & $\begin{array}{c}\text { Generated } \\
\text { Frequency } \\
\text { (p.u) Fuzzy }\end{array}$ \\
\hline 0.225 & 1.232 & 1.227 & 0.975 & 0.976 \\
0.538 & 1.434 & 1.430 & 0.961 & 0.962 \\
0.6389 & 1.526 & 1.525 & 0.957 & 0.956 \\
0.871 & 1.817 & 1.827 & 0.947 & 0.947 \\
\hline
\end{tabular}

Table 5. Magnetizing reactance and SEIG-generated frequency with varying speed for analytical and fuzzy techniques. Load $=230 \mathrm{Ohm}$, excitation capacitance $=22.00 \mu \mathrm{F}$.

\begin{tabular}{ccccc}
\hline $\begin{array}{c}\text { Speed } \\
\text { (p.u.) }\end{array}$ & $\begin{array}{c}\text { Magnetizing } \\
\text { Reactance (p.u.) } \\
\text { Analytical }\end{array}$ & $\begin{array}{c}\text { Magnetizing } \\
\text { Reactance (p.u.) } \\
\text { Fuzzy }\end{array}$ & $\begin{array}{c}\text { Generated } \\
\text { Frequency (p.u.) } \\
\text { Analytical }\end{array}$ & $\begin{array}{c}\text { Generated } \\
\text { Frequency (p.u.) } \\
\text { Fuzzy }\end{array}$ \\
\hline 0.923 & 1.969 & 1.9698 & 0.903 & 0.903 \\
0.953 & 1.844 & 1.846 & 0.932 & 0.932 \\
1.014 & 1.623 & 1.621 & 0.991 & 0.992 \\
1.071 & 1.448 & 1.443 & 1.047 & 1.047 \\
\hline
\end{tabular}

Table 6. Magnetizing reactance and SEIG-generated frequency with varying capacitance for analytical and fuzzy techniques. Speed $=1430 \mathrm{RPM}$, load $=178 \mathrm{Ohm}$.

\begin{tabular}{ccccc}
\hline $\begin{array}{c}\text { Capacitance } \\
\text { (p.u.) }\end{array}$ & $\begin{array}{c}\text { Magnetizing } \\
\text { Reactance (p.u.) } \\
\text { Analytical }\end{array}$ & $\begin{array}{c}\text { Magnetizing } \\
\text { Reactance (p.u.) } \\
\text { Fuzzy }\end{array}$ & $\begin{array}{c}\text { Generated } \\
\text { Frequency (p.u.) } \\
\text { Analytical }\end{array}$ & $\begin{array}{c}\text { Generated } \\
\text { Frequency } \\
\text { (p.u.)n Fuzzy }\end{array}$ \\
\hline 0.608 & 2.200 & 2.204 & 0.997 & 0.997 \\
0.665 & 1.985 & 1.986 & 0.997 & 0.997 \\
0.764 & 1.698 & 1.696 & 0.996 & 0.996 \\
0.830 & 1.549 & 1.547 & 0.995 & 0.996 \\
\hline
\end{tabular}


Table 7. Determination of capacitance requirement at constant air-gap voltage with varying load. Speed $=1485 \mathrm{RPM}$, excitation capacitance $=25.46 \mu \mathrm{F}$.

\begin{tabular}{ccccc}
\hline $\begin{array}{c}\text { Load } \\
\text { Admittance } \\
\text { (p.u) }\end{array}$ & $\begin{array}{c}\text { Air-Gap } \\
\text { Voltage } \\
\text { (p.u) }\end{array}$ & $\begin{array}{c}\text { Additional } \\
\text { Capacitance (p.u) } \\
\text { Fuzzy }\end{array}$ & $\begin{array}{c}\text { Additional } \\
\text { Capacitance (p.u) } \\
\text { Analytical }\end{array}$ & $\begin{array}{c}\text { Additional } \\
\text { Capacitance (p.u) } \\
\text { Standard Test }\end{array}$ \\
\hline 0.225 & 1.0 & 0.581 & 0.580 & 0.590 \\
0.413 & 1.0 & 0.633 & 0.632 & 0.651 \\
0.538 & 1.0 & 0.694 & 0.693 & 0.719 \\
0.580 & 1.0 & 0.694 & 0.693 & 0.719 \\
0.638 & 1.0 & 0.719 & 0.718 & 0.743 \\
0.819 & 1.0 & 0.805 & 0.806 & 0.832 \\
0.871 & 1.0 & 0.838 & 0.835 & 0.855 \\
0.948 & 1.0 & 0.882 & 0.881 & 0.895 \\
\hline
\end{tabular}

\subsection{Determination of Machine Parameters with Fuzzy-Logic Technique}

For the implementation of fuzzy technique on the machine under study, three cases are considered, in first case all parameters of machine are kept constant and load is varied in steps from no load to full load. The machine parameters as input to fuzzy logic are: stator and rotor resistance vary from 0.01-0.11 p.u, stator and rotor leakage reactance from $0.03-0.17$ p.u. The load power factor range is restricted to $0.85-1.0$. In second case all parameters of machine are kept constant and speed is varied $85-120 \%$ of base speed matching to rated frequency and load is kept at unity power factor. In third case all other parameters are kept constant and capacitance is varied from $65-110 \%$ of base capacitance. The results of these three cases are presented in Tables 4-6 and compared with analytical results.

At constant speed and a fixed excitation capacitance, as the machine load decreases, the machine's magnetizing reactance increases with a corresponding decrease in generated frequency.

At a constant load and fixed excitation capacitance, as machine speed increases, its magnetizing reactance decreases with a corresponding increase in generated frequency.

At constant speed and a fixed load, as machine excitation capacitance increases, its magnetizing reactance decreases with corresponding almost constantly generated frequency.

\subsection{Determination of Capacitance Requirement for Maintenance of Air-Gap Voltage}

After implementation of the fuzzy-logic model, the results are tabulated in Tables 7-10.

Table 8. Determination of terminal voltage and output power at constant air-gap voltage with varying load. Speed $=1485 \mathrm{RPM}$, excitation capacitance $=25.46 \mu \mathrm{F}$.

\begin{tabular}{ccccccc}
\hline $\begin{array}{c}\text { Load } \\
\text { Admittance } \\
\text { (p.u.) }\end{array}$ & $\begin{array}{c}\text { Terminal } \\
\text { Voltage } \\
\text { (p.u.) Fuzzy }\end{array}$ & $\begin{array}{c}\text { Terminal } \\
\text { Voltage (p.u.) } \\
\text { Analytical }\end{array}$ & $\begin{array}{c}\text { Terminal } \\
\text { Voltage (p.u.) } \\
\text { Standard Test }\end{array}$ & $\begin{array}{c}\text { Output } \\
\text { Power (p.u.) } \\
\text { Fuzzy }\end{array}$ & $\begin{array}{c}\text { Output } \\
\text { Power (p.u.) } \\
\text { Analytical }\end{array}$ & $\begin{array}{c}\text { Output Power } \\
\text { (p.u.) Standard } \\
\text { Test }\end{array}$ \\
\hline 0.225 & 1.031 & 1.017 & 1.028 & 0.718 & 0.698 & 0.709 \\
0.413 & 1.015 & 0.998 & 1.014 & 1.251 & 1.236 & 1.249 \\
0.538 & 0.996 & 0.987 & 0.997 & 1.665 & 1.574 & 1.600 \\
0.580 & 0.995 & 0.983 & 0.995 & 1.732 & 1.686 & 1.710 \\
0.638 & 0.993 & 0.978 & 0.992 & 1.875 & 1.836 & 1.861 \\
0.819 & 0.987 & 0.964 & 0.980 & 2.305 & 2.283 & 2.308 \\
0.871 & 0.966 & 0.959 & 0.966 & 2.443 & 2.408 & 2.431 \\
0.948 & 0.956 & 0.954 & 0.956 & 2.621 & 2.590 & 2.610 \\
\hline
\end{tabular}


Table 9. Determination of capacitance requirement at constant air-gap voltage with varying speed. Load $=165$ Ohm, excitation capacitance $=25.46 \mu \mathrm{F}$.

\begin{tabular}{ccccc}
\hline $\begin{array}{c}\text { Speed } \\
\text { (p.u) }\end{array}$ & $\begin{array}{c}\text { Air gap } \\
\text { Voltage (p.u.) }\end{array}$ & $\begin{array}{c}\text { Additional } \\
\text { Capacitance (p.u.) } \\
\text { Fuzzy }\end{array}$ & $\begin{array}{c}\text { Additional } \\
\text { Capacitance (p.u.) } \\
\text { Analytical }\end{array}$ & $\begin{array}{c}\text { Additional } \\
\text { Capacitance (p.u.) } \\
\text { Standard Test }\end{array}$ \\
\hline 0.903 & 1.0 & 0.583 & 0.583 & 0.583 \\
0.912 & 1.0 & 0.644 & 0.643 & 0.634 \\
0.938 & 1.0 & 0.649 & 0.648 & 0.648 \\
0.955 & 1.0 & 0.703 & 0.703 & 0.704 \\
0.970 & 1.0 & 0.726 & 0.726 & 0.725 \\
0.990 & 1.0 & 0.791 & 0.790 & 0.791 \\
1.104 & 1.0 & 0.837 & 0.837 & 0.837 \\
1.036 & 1.0 & 0.887 & 0.887 & 0.888 \\
& $(18)$ & & & \\
\hline
\end{tabular}

Table 10. Determination of terminal voltage andoOutput power at constant air-gap voltage with varying speed. Load $=165 \mathrm{Ohm}$, excitation capacitance $=25.46 \mu \mathrm{F}$.

\begin{tabular}{ccccccc}
\hline $\begin{array}{c}\text { Speed } \\
\text { (p.u) }\end{array}$ & $\begin{array}{c}\text { Terminal } \\
\text { Voltage (p.u) } \\
\text { Fuzzy }\end{array}$ & $\begin{array}{c}\text { Terminal } \\
\text { Voltage (p.u) } \\
\text { Analytical }\end{array}$ & $\begin{array}{c}\text { Terminal } \\
\text { Voltage (p.u) } \\
\text { Standard Test }\end{array}$ & $\begin{array}{c}\text { Output } \\
\text { Power (p.u) } \\
\text { Fuzzy }\end{array}$ & $\begin{array}{c}\text { Output } \\
\text { Power (p.u) } \\
\text { Analytical }\end{array}$ & $\begin{array}{c}\text { Output Power } \\
\text { (p.u) Standard } \\
\text { Test }\end{array}$ \\
\hline 0.903 & 0.792 & 0.792 & 0.793 & 1.0078 & 0.9861 & 0.9917 \\
0.912 & 0.792 & 0.792 & 0.795 & 1.0373 & 1.0189 & 1.0234 \\
0.938 & 0.818 & 0.818 & 0.815 & 1.1436 & 1.123 & 1.1235 \\
0.953 & 0.849 & 0.849 & 0.845 & 1.3083 & 1.2972 & 1.2944 \\
0.970 & 0.873 & 0.873 & 0.876 & 1.4263 & 1.4162 & 1.4124 \\
0.990 & 0.889 & 0.889 & 0.887 & 1.6021 & 1.5849 & 1.581 \\
1.104 & 0.905 & 0.901 & 0.905 & 1.7323 & 1.7173 & 1.7145 \\
1.036 & 0.906 & 0.905 & 0.903 & 1.8703 & 1.857 & 1.8575 \\
\hline
\end{tabular}

At constant speed and fixed excitation capacitance against the maintenance of constant air-gap voltage, as load admittance increases, the corresponding requirement of additional capacitance also increases.

At constant speed and fixed excitation capacitance against the maintenance of constant air-gap voltage, as load admittance increases, the corresponding terminal voltage decreases and output power increases, as described in Figures 5 and 6.

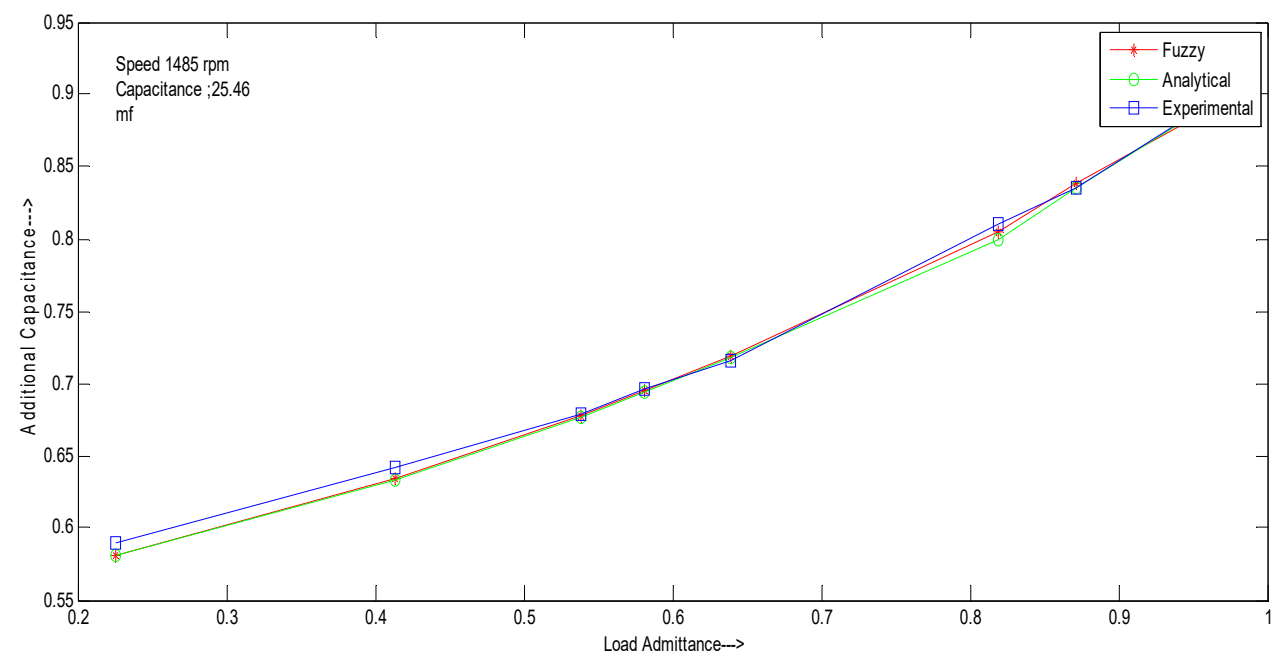

Figure 5. Comparison of additional capacitance vs. load admittance for three techniques. 


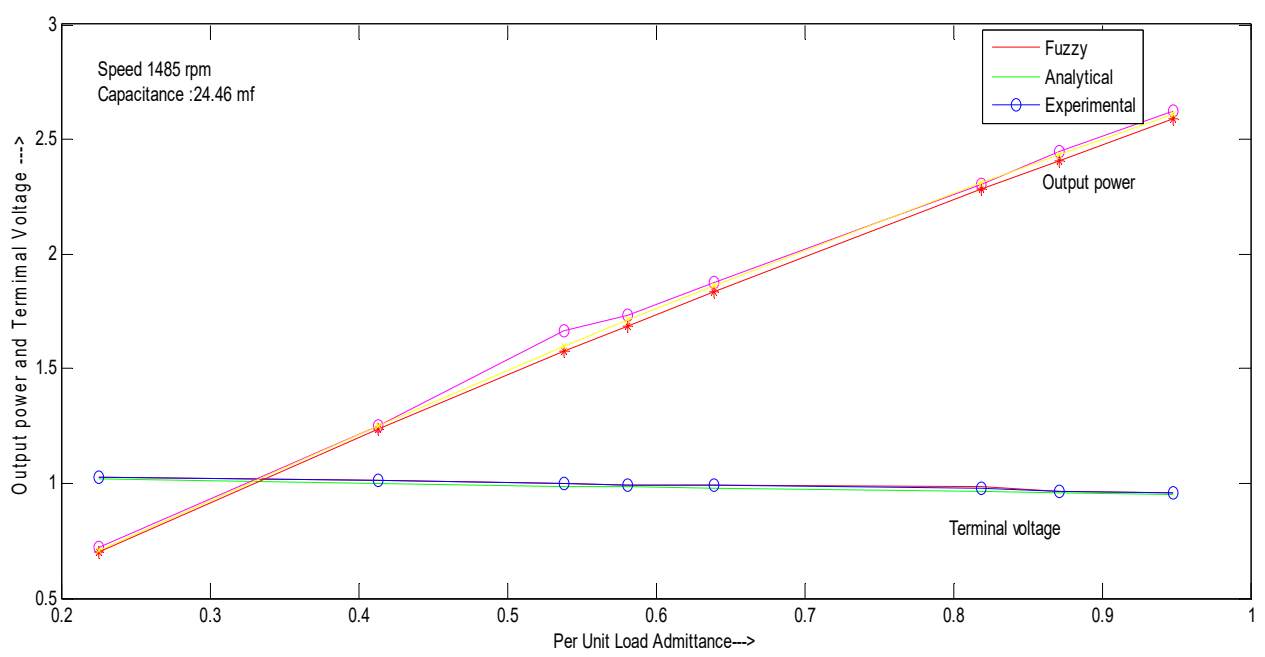

Figure 6. Output power and terminal voltage vs. load admittance for three techniques.

At a constant load and fixed excitation capacitance against the maintenance of constant air-gap voltage, as the speed increases, the corresponding terminal voltage and output power increase, as described in Figures 7 and 8.

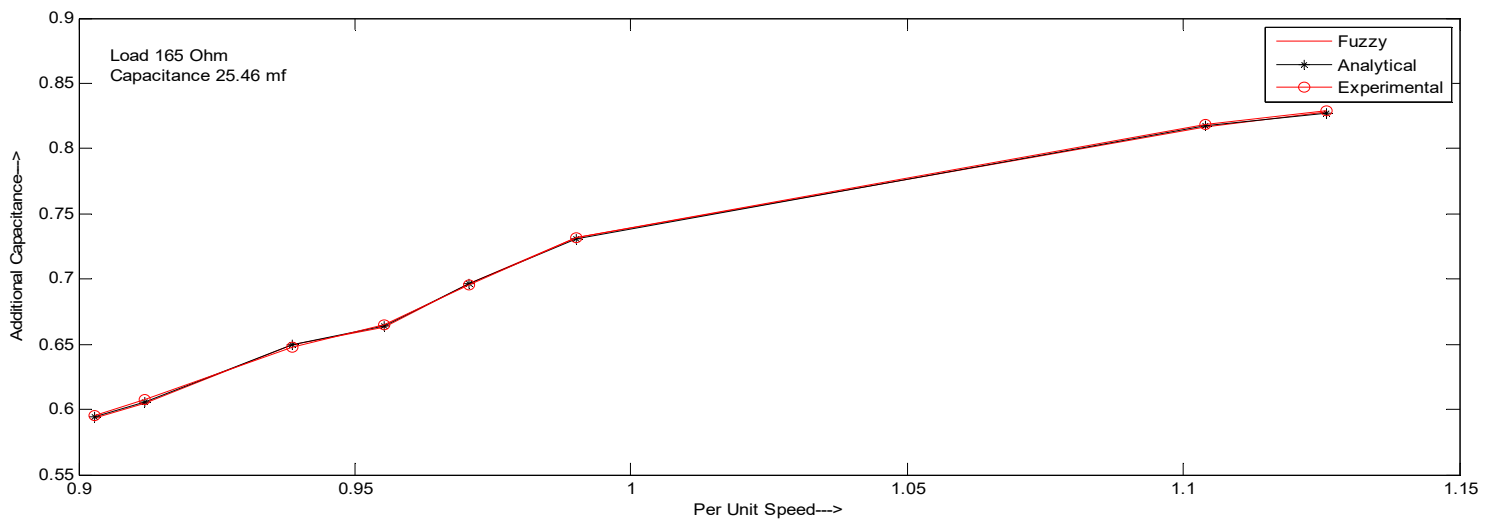

Figure 7. Comparison of additional capacitance vs. speed for three techniques.

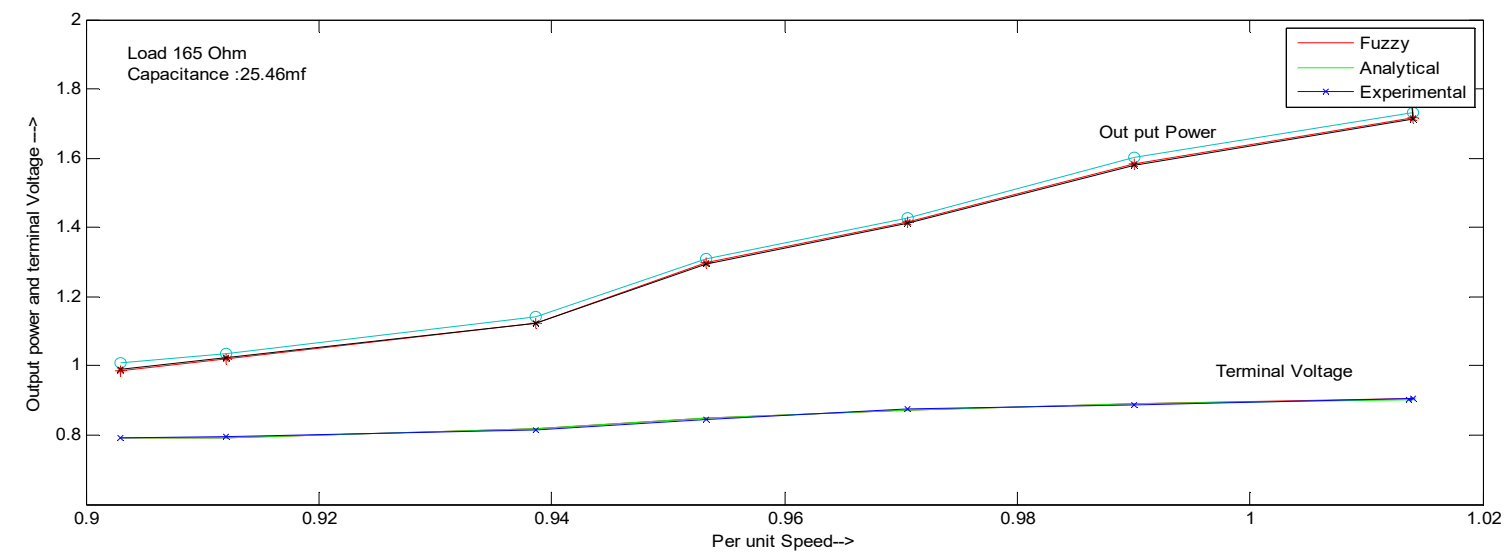

Figure 8. Output power and terminal voltage vs. speed for three techniques.

For sustainability of constant air-gap voltage under variable or operating conditions, the combination of parameter values is the most important factor. Fuzzy logic is fairly intelligent at handling these variations or transient conditions, with a careful selection of a parameter range in fuzzy rules, such as stator resistance, rotor resistance, and inductances of stator and rotor, which has 
significant effect on initialization and early transient settlement. The occurrence of overvoltages and overcurrents due to transients or due to unpractical changes in excitation capacitance may lead the machine out of synchronism and generation capability.

\subsection{Comparison of Heuristic Methods}

Heuristic methods are experience-based methods that reduce the effort of calculations and time for any particular machine or equipment under different operating conditions. The fuzzy-logic technique is basically a heuristic method as, when accurate decisions are not possible due to complexity in system parameters, an optimal, flexible, and smooth decision can be met out of fuzzy decision-making. Similar soft computation-based techniques, like artificial intelligence and optimization techniques, are implemented in SEIG by various researchers for performance analysis, evaluation of frequency, air-gap voltage, and capacitance requirements. Joshi et al (2006) used an Artificial Neural Network for SEIG performance analysis [45]. Khela et al., (2011) implemented the Artificial Neural Network model for capacitance estimation to maintain constant air-gap voltage [24]. Mohamed Enany (2014) conducted steady-state SEIG modeling and analysis by using an Adaptive Neurofuzzy Inference System (ANFIS) [46]. The present paper has proposed and implemented the fuzzy technique for capacitance assessment in sustaining constant air-gap voltage under variable conditions. All contributions of researchers evidently support the applications of these techniques for SEIG analysis, but results might not be compared directly, as parameters of the machine under study vary for each study.

\section{Conclusions}

A Self-Excited Induction Generator has the capacity to work in an isolated mode for power generation as distributed generation in remote locations or near load centers. For the generation of enough voltage and sufficient frequency, the chief requirement of this generator is reactive power, which can be met by installing a capacitor bank on stator terminals. However, the dependence of these essential parameters, output voltage, and frequency on speed, load, and capacitance, imposes a restriction on its usage. During operation of an SEIG, speed, load, and capacitance are continuously varying parameters, which further affect output voltage and frequency. To determine suitable capacitance under varying speed and load conditions, a fuzzy-logic technique has shown promising results. The result shows that at constant air-gap voltage 1.0 p.u. and rated frequency, the required capacitance range is $0.581-0.882$ p.u., corresponding to a varying load of $0.225-0.948$ p.u. At this stage, the terminal voltage and output power available at generator terminals are in the range of 1.01-0.950 p.u. and 0.718-2.621 p.u., respectively. Further, at constant air-gap voltage, 1.0 p.u. and rated frequency, the required capacitance range is $0.583-0.887 \mathrm{p} . \mathrm{u}$. corresponding to a varying speed of 0.903-1.036 p.u. During this, the terminal voltage and output power available at generator terminals are in the range of 0.792-0.906 p.u. and 0.698-2.594 p.u., respectively. Hence, this study concludes that, to maintain constant air-gap voltage, a total capacitance of 14.79 to $22.47 \mu \mathrm{F}$ is required under a varying load of 427 to $101 \mathrm{ohms}$, and total capacitance of 13.70 to $22.59 \mu \mathrm{F}$ is required under a varying speed of 1349 to 1672 RPM.

To test the fuzzy results, the same SEIG was also placed for analytical and standard-test techniques. The results collected from all the three techniques are comparable. For the verification of the fuzzy-logic technique for an SEIG, the determination of machine parameters was done through standard tests and analytical technique, and results verified with the implementation of the fuzzy model. It is valid that the fuzzy-logic technique of artificial intelligence has enough intelligence to select suitable capacitance for any SEIG without following conventional analytical and standard-test techniques.

Author Contributions: A.S. contributed comprehensively to writing the original draft of manuscript; G.K. gave the technical advice and improved the writing, review, and editing of the manuscript; both the authors have approved the submission of manuscript.

Funding: This research has not received any external funds. 
Acknowledgments: This study is based on the doctorate thesis of the first author, who is research scholar at I.K.Gujral Punjab Technical University Jalandhar, Kapurthala and wants to affectionately express his gratitude to mentor Gagandeep Kaur. Authors are deeply indebted to the authorities of the Giani Zail Singh Campus, College of Engineering and Technology, Bathinda, Punjab, India for use of their lab facility. Authors are grateful to the authorities of the I. K. Gujral Punjab Technical University, Jalandhar, Punjab, India for their academic and technical support. Authors have a deep sense of gratitude and appreciation for Dr. Raja Singh Khela, Director-Principal, Doaba Group of Colleges, Kharar, Mohali, India for his technical advice during the completion of this study.

Conflicts of Interest: No potential conflict of interest reported by authors.

\section{Nomenclature}

$\mathrm{R}_{\mathrm{S}} \mathrm{X}_{\mathrm{S}}=$ stator resistance and reactance

$\mathrm{R}_{\mathrm{r}} \mathrm{X}_{\mathrm{r}}=$ rotor resistance and reactance

$\mathrm{RL}, \mathrm{X}_{\mathrm{L}}=$ load resistance and reactance

$\mathrm{R}_{\mathrm{e}}=$ core loss resistance

$\mathrm{a}=$ generated frequency

$\mathrm{I}_{\mathrm{S}}=$ stator current

$\mathrm{I}_{\mathrm{L}}=$ load current

$\mathrm{E}_{1}=$ per phase air gap voltage

Polynomial coefficients:

$\mathrm{P} 1=\left(\mathrm{X}_{1 \mathrm{~s}} \mathrm{X}_{1 \mathrm{r}} \mathrm{X}_{\mathrm{L}}\right)$

$\mathrm{P} 2=\left(\mathrm{X}_{1 \mathrm{~s}} \mathrm{X}_{1 \mathrm{r}} \mathrm{X}_{\mathrm{L}}\right) \mathrm{b}$

$\left.\mathrm{P} 3=\mathrm{X}_{1 \mathrm{~s}} \mathrm{R}_{\mathrm{r}} \mathrm{R}_{\mathrm{L}}+\mathrm{R}_{\mathrm{e}} \mathrm{R}_{\mathrm{L}}+\mathrm{X}_{1 \mathrm{r}} \mathrm{X}_{\mathrm{c}}\right)+\mathrm{X}_{1 \mathrm{r}}\left(\mathrm{R}_{\mathrm{e}} \mathrm{R}_{1}+\mathrm{X}_{\mathrm{c}} \mathrm{X}_{\mathrm{L}}+\mathrm{R}_{\mathrm{s}} \mathrm{R}_{\mathrm{L}}\right)+$

$X_{L}\left(R_{e} R_{r}+R_{e} R_{s}+R_{S} R_{r}\right)$

$\mathrm{P} 4=\mathrm{X}_{1 \mathrm{~s}} \mathrm{R}_{\mathrm{e}}\left(\mathrm{X}_{1 \mathrm{r}} \mathrm{R}_{\mathrm{L}}+\mathrm{R}_{\mathrm{r}} \mathrm{X}_{\mathrm{L}}\right)+\mathrm{R}_{\mathrm{e}} \mathrm{R}_{\mathrm{s}} \mathrm{X}_{\mathrm{lr}} \mathrm{X}_{\mathrm{L}}$

$\mathrm{P} 5=-\mathrm{X}_{1 \mathrm{~s}}\left(\mathrm{X}_{1 \mathrm{r}} \mathrm{X}_{\mathrm{c}}+\mathrm{R}_{\mathrm{e}} \mathrm{R}_{\mathrm{L}}\right) \mathrm{b}-\mathrm{X}_{1 \mathrm{r}}\left(\mathrm{R}_{\mathrm{s}} R_{\mathrm{L}}+\mathrm{R}_{\mathrm{e}} \mathrm{R}_{\mathrm{L}}+\mathrm{X}_{\mathrm{c}} \mathrm{X}_{\mathrm{L}}\right) \mathrm{b}-$

$\left(\mathrm{R}_{\mathrm{S}} \mathrm{R}_{\mathrm{e}} \mathrm{X}_{\mathrm{L}}\right) \mathrm{b}$

$\mathrm{P} 6=-\mathrm{X}_{1 \mathrm{r}} \mathrm{R}_{\mathrm{e}}\left(\mathrm{R}_{\mathrm{S}} \mathrm{X}_{\mathrm{L}}+\mathrm{X}_{1 \mathrm{~s}} \mathrm{R}_{\mathrm{L}}\right) \mathrm{b}$

$P 7=X_{c} R_{r}\left(R_{s}+R_{L}\right)-X_{c} R_{e}\left(R_{s}+R_{L}+R_{r}\right)$

$\mathrm{P} 8=\left(\mathrm{R}_{\mathrm{e}} \mathrm{X}_{1 \mathrm{r}} \mathrm{X}_{\mathrm{c}}\left(\mathrm{R}_{\mathrm{L}}+\mathrm{R}_{\mathrm{s}}\right)-\left(\mathrm{R}_{\mathrm{e}} \mathrm{R}_{\mathrm{r}} \mathrm{X}_{\mathrm{c}}\left(\mathrm{X}_{\mathrm{L}}+\mathrm{X}_{1 \mathrm{~s}}\right)-\left(\mathrm{R}_{\mathrm{e}} \mathrm{R}_{\mathrm{s}} \mathrm{R}_{\mathrm{r}} \mathrm{R}_{\mathrm{L}}\right)\right.\right.$

$\mathrm{P} 9=\mathrm{R}_{\mathrm{e}} \mathrm{X}_{\mathrm{c}}\left(\mathrm{R}_{\mathrm{s}}+\mathrm{R}_{\mathrm{L}}\right) \mathrm{b}$

$\mathrm{P} 10=\mathrm{X}_{\mathrm{c}} \mathrm{X}_{1 \mathrm{r}} \mathrm{R}_{\mathrm{e}}\left(\mathrm{R}_{\mathrm{L}}+\mathrm{R}_{\mathrm{S}}\right) \mathrm{b}$

$\mathrm{Q} 1=\mathrm{X}_{1 \mathrm{~s}} \mathrm{X}_{\mathrm{L}}\left(\mathrm{R}_{\mathrm{e}}+\mathrm{R}_{\mathrm{r}}\right)+\mathrm{X}_{1 \mathrm{~s}} \mathrm{X}_{1 \mathrm{r}} \mathrm{R}_{\mathrm{L}}+\mathrm{X}_{1 \mathrm{r}} \mathrm{X}_{\mathrm{L}}\left(\mathrm{R}_{\mathrm{e}}+\mathrm{R}_{\mathrm{s}}\right)$

$\mathrm{Q} 2=\mathrm{X}_{1 \mathrm{~s}} \mathrm{X}_{1 \mathrm{r}} \mathrm{X}_{\mathrm{L}} \mathrm{R}_{\mathrm{e}}$

$\mathrm{Q} 3=-\mathrm{X}_{1 \mathrm{~s}}\left(\mathrm{R}_{\mathrm{e}} \mathrm{X}_{\mathrm{L}}+\mathrm{X}_{1 \mathrm{r}} \mathrm{R}_{\mathrm{L}}\right) \mathrm{b}-\mathrm{X}_{1 \mathrm{r}} \mathrm{X}_{\mathrm{L}}\left(\mathrm{R}_{\mathrm{S}}+\mathrm{R}_{\mathrm{e}}\right) \mathrm{b}$

$\mathrm{Q} 4=-\left(\mathrm{X}_{1 \mathrm{~s}} \mathrm{X}_{1 \mathrm{r}} \mathrm{X}_{\mathrm{L}} \mathrm{R}_{\mathrm{e}}\right) \mathrm{b}$

$\mathrm{Q} 5=-\mathrm{X}_{\mathrm{c}} \mathrm{R}_{\mathrm{e}}\left(\mathrm{X}_{1 \mathrm{~s}}+\mathrm{X}_{1 \mathrm{r}}+\mathrm{X}_{\mathrm{L}}\right)-\mathrm{R}_{\mathrm{L}} \mathrm{R}_{\mathrm{e}}\left(\mathrm{R}_{\mathrm{S}}+\mathrm{R}_{\mathrm{r}}\right)-\mathrm{R}_{\mathrm{L}}\left(\mathrm{X}_{1 \mathrm{r}} \mathrm{X}_{\mathrm{C}}+\right.$

$\left.R_{r} R_{s}\right)-X_{c}\left(R_{s} X_{1 r}+X_{1 s} R_{r}+X_{L} R_{r}\right)$

$\mathrm{Q} 6=-\mathrm{R}_{\mathrm{e}} \mathrm{X}_{1 \mathrm{r}}\left(\mathrm{X}_{1 \mathrm{~s}} \mathrm{X}_{\mathrm{c}}+\mathrm{X}_{\mathrm{c}} \mathrm{X}_{\mathrm{L}}+\mathrm{R}_{\mathrm{s}} \mathrm{R}_{\mathrm{L}}\right)-\mathrm{R}_{\mathrm{r}} \mathrm{R}_{\mathrm{e}}\left(\mathrm{X}_{1 \mathrm{~s}} \mathrm{R}_{\mathrm{L}}+\mathrm{R}_{\mathrm{s}} \mathrm{X}_{\mathrm{L}}\right)$

$\mathrm{Q} 7=\mathrm{R}_{\mathrm{e}}\left(\mathrm{X}_{1 \mathrm{r}} \mathrm{X}_{\mathrm{c}}+\mathrm{X}_{1 \mathrm{~s}} \mathrm{X}_{\mathrm{c}}+\mathrm{X}_{\mathrm{L}}+\mathrm{R}_{\mathrm{s}} \mathrm{R}_{\mathrm{l}}\right) \mathrm{b}+\mathrm{X}_{\mathrm{c}} \mathrm{X}_{1 \mathrm{r}}\left(\mathrm{R}_{\mathrm{s}}+\mathrm{R}_{\mathrm{L}}\right) \mathrm{b}$

$\mathrm{Q} 8=\mathrm{R}_{\mathrm{e}} \mathrm{X}_{1 \mathrm{r}}\left(\mathrm{X}_{1 \mathrm{~s}} \mathrm{X}_{\mathrm{c}}+\mathrm{X}_{\mathrm{c}} \mathrm{X}_{\mathrm{L}}\right) \mathrm{b}+\left(\mathrm{X}_{1 \mathrm{r}} \mathrm{R}_{\mathrm{e}} \mathrm{R}_{\mathrm{L}} \mathrm{R}_{\mathrm{s}}\right) \mathrm{b}$

$\mathrm{Q} 9=\mathrm{R}_{\mathrm{e}} X_{\mathrm{c}} \mathrm{R}_{\mathrm{r}}\left(\mathrm{R}_{\mathrm{L}}+\mathrm{R}_{\mathrm{s}}\right)$
$X_{m}=$ saturated magnetizing reactance

$\mathrm{X}_{\mathrm{mu}}=$ Unsaturated magnetizing reactance

$\mathrm{X}_{\mathrm{c}}=$ per-phase capacitive reactance

$\mathrm{b}=$ ratio of actual speed to synchronous speed

$\mathrm{I}_{\mathrm{r}}=$ rotor current

$\mathrm{I}_{\mathrm{C}}=$ capacitive current

$\mathrm{Z}=$ impedance

\section{References}

1. Kaur, G.; Brar, Y.S.; Kothari, D.P. Potential of Livestock Generated Biomass: Untapped Energy Source in India. Energies 2017, 10, 847. [CrossRef]

2. Pillay, A.; Karthikeyan, S.P.; Kothari, D.P. Congestion management in power system: A review. Int. J. Electr. Power Energy Syst. 2015, 70, 83-90. [CrossRef]

3. Bansal, R.C.; Bhatti, T.S.; Kothari, D.P. A bibliographical survey on induction generators for application of nonconventional energy systems. IEEE Trans. Energy Convers. 2003, 18, 433-439. [CrossRef]

4. Khan, F.; Khan, R.; Kouzou, A. Three phase self-excited induction generator for renewable energy generation. In Proceedings of the 1st International Conference on Power Electronics and their Applications, Djelfa, Algeria, 6-7 November 2013. [CrossRef] 
5. Grantham, C.; Rahman, F.; Seyoum, D. A regulated self-excited induction generator for use in a remote area power supply. In Proceedings of the 6th International Conference on Electrical Machines and Drives (Conf. Publ. No. 376), Oxford, UK, 8-10 September 1993.

6. Bansal, R.C.; Bhatti, T.S.; Kothari, D.P. Induction generator for isolated hybrid power system applications: A review. J. Inst. Eng. (India) 2003, 83, 262-269.

7. Faisal Khan, M.; Rizwan, M. Comprehensive analytical and experimental analysis of a self excited induction generator for renewable energy applications. Int. J. Renew. Energy Res. 2015, 5, 747-756.

8. Nagrath, I.J.; Kothari, D.P. Electrical Machines; Tata McGraw-Hill: New York, NY, USA, 1997.

9. Bansal, R.; Bhatti, T.; Kothari, D. On some of the design aspects of wind energy conversion systems. Energy Convers. Manag. 2002, 43, 2175-2187. [CrossRef]

10. Farrag, M.E.; Putrus, G.A. Analysis of the Dynamic Performance of Self-Excited Induction Generators Employed in Renewable Energy Generation. Energies 2014, 7, 278-294. [CrossRef]

11. Goyal, S.K.; Palwalia, D.K. Analysis of performance parameters and estimation of optimum capacitance for asynchronous generator. Sci. Technol. Int. J. 2016, 19, 1753-1762. [CrossRef]

12. Basset, E.D.; Potter, F.M. Capacitive excitation for induction generator. AIEE Trans. (Electr. Eng.) 1935, 54, 540-545. [CrossRef]

13. Hammad, A.E.; Mathur, R.M. New generalized concept for the design of thyristor phase controlled var compensator. IEEE Trans. Power Appar. Syst. 1977, 98, 219-231. [CrossRef]

14. Ooi, B.T.; David, R.A. Induction generator/synchronous condenser system for wind turbine power. IEE Proc. 1979, 126, 69-74. [CrossRef]

15. Singh, S.P.; Singh, B.; Jain, M.P. Performance characteristics and optimum utilization of a cage Machine as capacitor excited induction generator. IEEE Trans. Energy Convers. 1990, 5, 679-684. [CrossRef]

16. Murthy, S.S. A novel self-excited self-regulated single phase Induction generator, Part 1: Basic system and theory. IEEE Trans. Energy Convers. 1993, 8, 377-382. [CrossRef]

17. Bim, E.; Szajner, J.; Burian, Y. Voltage compensation of an induction generator with long shunt. IEEE Trans. Energy Convers. 1995, 10, 305-313. [CrossRef]

18. Ojo, O. Performance of self-excited single-phase induction generators with shunt, short-shunt and long-shunt excitation connections. IEEE Trans. Energy Convers. 1996, 11, 477-482. [CrossRef]

19. Wang, L.; Su, J.Y. Dynamic performances of an isolated self-excited induction generator under various loading conditions. IEEE Trans. Energy Convers. 1999, 14, 93-100. [CrossRef]

20. Chan, T.F.; Lai, L.L. Capacitance requirements of a three-phase induction generator self-excited with a single capacitance and supplying a single-phase load. IEEE Trans. Energy Convers. 2002, 17, 90-94. [CrossRef]

21. Seyoum, D.; Grantham, C.; Rahman, M.F. The dynamic characteristics of an isolated self-excited induction generator driven by a wind turbine. IEEE Trans. Ind. Appl. 2003, 39, 936-944. [CrossRef]

22. Ahmed, T.; Noro, O.; Matzuo, K.; Shindo, Y.; Nakaoka, M. Minimum Excitatauion capacitance requirements for wind turbine coupled stand alone self excited induction generator with voltage regulation based on SVC. In Proceedings of the 25th International Telecommunications Energy Conference, Yokohama, Japan, 23-23 October 2003.

23. Singh, G.K.; Kumar, A.S.; Saini, R.P. Selection of capacitor for the self-excited six-phase induction generator. In Proceedings of the International Conference on Power Systems, Kharagpur, India, 27-29 December 2009.

24. Khela, R.S.; Sandhu, K.S. ANN model for estimation of capacitance requirements to maintain constant air gap voltage of self excited induction generator with variable load. Int. J. Comput. Sci. Technol. 2011, 2, 53-57.

25. Haque, M.H.; Maswood, A.I. Determination of excitation capacitance of a three-phase self-excited induction generator. In Proceedings of the IEEE Power and Energy Society General Meeting, San Diego, CA, USA, 22-26 July 2012.

26. Kumar, S.; Pradhan, S.; Sahu, R.N. Excitation capacitance requirement of three phase self excited induction generator for wind mill applications. In Proceedings of the International Conference on Energy Efficient Technologies for Sustainability, Nagercoil, India, 10-12 April 2013.

27. Abbou, A.; Barara, M.; Ouchatti, A.; Akherraz, M.; Mahmoudi, H. Capacitance required analysis for self excited induction generator. J. Theor. Appl. Inf. Technol. 2013, 55, 382-389.

28. Khan, M.F.; Khan, M.R. Evaluation of excitation capacitance for a single-phase two winding self excited induction generator. In Proceedings of the IEEE International Conference on Power Electronics, Drives and Energy Systems (PEDES), Mumbai, India, 16-19 December 2014. 
29. Mohanty, A.K.; Yadav, K.B. Estimation of excitation capacitance requirement of an isolated multi-phase induction generator for power generation. Int. J. Power Electron. Drive Syst. (IJPEDS) 2016, 7, 561-567. [CrossRef]

30. Mhamdi, T.; Barhoumi, A.; Sabita, L. Stand-alone self excited induction generator driven by wind turbine. Alex. Eng. J. 2017. [CrossRef]

31. Sakkoury, K.S.; Emara, S.; Ahmed, M.K. Analysis of wind driven self-excited induction generator supplying isolated DC loads. J. Electr. Syst. Inf. Technol. 2017, 4, 257-268. [CrossRef]

32. Quazene, L.; McPherson, G. Analysis of an isolated induction generator. IEEE Trans. Power Appl. Syst. 1983, 102, 2793-2798. [CrossRef]

33. Al-Bahrani, A.H.; Malik, N.H. Steady-state analysis and performance characteristic of a 3-phase induction generator self-excited with a single capacitor. IEEE Trans. Energy Convers. 1990, 5, 725-732. [CrossRef]

34. Murthy, S.S.; Malik, O.P.; Tandon, A.K. Analysis of self excited induction generator. IEE Proc. C (Gener. Transm. Distrib.) 1982, 129, 260-265. [CrossRef]

35. Narayanan, S.S.Y.; Johnny, V.J. Contribution to the steady state analysis of wind-turbine driver self-excited induction generator. IEEE Trans. Energy Convers. 1986, 1, 169-176. [CrossRef]

36. Raina, G.; Malik, O.P. Wind energy conversion using a self-excited induction generator. IEEE Trans. Power Appar. Syst. 1983, 12, 3933-3936. [CrossRef]

37. Singh, S.P.; Singh, B.; Jain, M.P. Steady state analysis of self excited pole changing induction generator. J. Inst. Eng. 1992, 73, 137-144.

38. Krause, P.C.; Thomas, C.H. Simulation of symmetrical induction machinery. IEEE Trans. Power Appar. 1965, 11, 1038-1053. [CrossRef]

39. Tandon, A.K.; Murthy, S.S.; Berg, G.J. Steady state analysis of capacitor self-excited induction generators. IEEE Trans. Power Appar. Syst. 1984, 3, 612-618. [CrossRef]

40. Bansal, R.C. Automatic Reactive Power Control of Autonomous Hybrid Power Systems. Ph.D. Thesis, Indian Institute of Technology, Delhi, India, 2002.

41. Bansal, R.C.; Bhatti, T.S.; Kothari, D.P. A novel mathematical modelling of induction generator for reactive power control of isolated hybrid power systems. Int. J. Model. Simul. 2004, 24, 1-7. [CrossRef]

42. Sandhu, K.S.; Jain, S.K. Operational Aspects of SEIG Using a New Model. Electr. Mach. Power Syst. 1999, 27, 169-180. [CrossRef]

43. Khan, M.F.; Khan, M.R.; Iqbal, A. Performance Analysis of Shunt, Short Shunt and Long Shunt Self excited induction generator: Analysis of Shunt, Short Shunt and Long Shunt SEIG. In Proceedings of the IEEE International Conference on Power Electronics, Drives and Energy Systems (PEDES), Bengaluru, India, 16-19 December 2012.

44. Chan, T.F. Capacitive requirements of self-excited induction generators. IEEE Trans. Energy Convers. 1993, 8, 304-311. [CrossRef]

45. Joshi, D.; Sandhu, K.S.; Soni, M.K. Performance analysis of self excited induction generator using artificial neural network. Iran. J. Electr. Comput. Eng. 2006, 5, 57-62.

46. Enany, M.A. Steady State Modeling and ANIFS based Analysis of self excited induction generator. Wind Eng. 2014, 38, 229-238. [CrossRef]

(c) 2018 by the authors. Licensee MDPI, Basel, Switzerland. This article is an open access article distributed under the terms and conditions of the Creative Commons Attribution (CC BY) license (http://creativecommons.org/licenses/by/4.0/). 